\title{
Efektivitas Penerapan Scaffolding terhadap Self Efficacy Mahasiswa pada Mata Kuliah Matematika Ekonomi di Program Studi Pendidikan Ekonomi STKIP Kumala Lampung
}

\author{
Wahyu Nofiansyah \\ STKIP Kumala Lampung Metro \\ wahyu.nofiansyah@kumala.ac.id
}

\begin{tabular}{l}
\hline \hline Article Info \\
\hline Article history: \\
Received Nov $11^{\text {th }} 2021$ \\
Revised Nov $23^{\text {th }} 2021$ \\
Accepted Nov $28^{\text {th }} 2021$ \\
\hline
\end{tabular}

Keywords:

Scaffolding;

Self efficacy;

Economic Mathematics

\begin{abstract}
The problem in this study is that students' self efficacy is still lacking in the learning process which has an impact on the final value of the economic mathematics course. This study aims to determine the effectiveness of the application of scaffolding on student self efficacy in the economic mathematics course of STKIP Kumala Lampung Metro. This research is an experimental research with one group pretest-posttest design. The population in this study were all students of Economic Education in the fourth semester of the 2020/2021 academic year, while the sample consisted of 30 students. The sampling technique used is saturated sampling. The data collection technique was done by using a questionnaire. In this study, prerequisite tests and data analysis processes, both from normality tests and hypothesis testing, use the help of SPSS data processing applications. The results obtained that the distribution is normal, then the t-test with a sig level of $5 \%$ obtained the results $t_{\text {hitung }}(3,161)>t_{\text {tabel }}(2,045)$ which means there is a difference between before and after the application of scaffolding on students' self efficacy. Furthermore, for the effect size test results obtained 0.577 which means it is included in the medium category. So it can be concluded that there is an effectiveness of the application of scaffolding on the self efficacy of students in the economics mathematics course.
\end{abstract}
Kata Kunci:
Abstrak
Scaffolding;
Self efficacy;
Matematika Ekonomi
Permasalahan dalam penelitian ini mengenai kepercayaan diri mahasiswa masih kurang dalam proses pembelajaran yang berdampak pada nilai akhir mata kuliah matematika ekonomi. Penelitian ini bertujuan 
untuk mengetahui efektivitas penerapan scaffolding terhadap self efficacy mahasiswa pada mata kuliah matematika ekonomi STKIP Kumala Lampung Metro. Penelitian ini merupakan penelitian eksperimen dengan one group pretest-posttest design. Populasi dalam penelitian ini adalah seluruh mahasiswa Pendidikan Ekonomi semester IV tahun akademik 2020/2021, sedangkan sampel berjumlah 30 orang mahasiswa. Adapun teknik pengambilan sampel yang digunakan adalah sampling jenuh. Teknik pengumpulan data dilakukan dengan angket. Dalam penelitian ini, uji prasyarat dan proses analisis data baik dari uji normalitas maupun uji hipotesis menggunakan bantuan aplikasi olah data SPSS. Hasil yang diperoleh bahwa berdistribusi normal, kemudian uji- $t$ dengan taraf sig 5\% didapat hasil $t_{\text {hitung }}(3,161)>t_{\text {tabel }}(2,045)$ yang berarti ada perbedaan antara sebelum dan sesudah penerapan scaffolding terhadap self efficacy mahasiswa. Selanjutnya untuk hasil uji effect size didapat 0,577 yang berarti termasuk kategori sedang. Maka dapat disimpulkan terdapat keefektifan penerapan scaffolding terhadap self efficacy mahasiswa pada mata kuliah matematika ekonomi.

\section{PENDAHULUAN}

Matematika Ekonomi merupakan salah satu mata kuliah wajib yang ada di Program Studi Pendidikan Ekonomi. Mata kuliah ini sangat berkaitan erat dengan perhitungan matematis, sehingga diperlukan pengetahuan konseptual terlebih dahulu. Artinya ilmu dasar guna diterapkan dalam kehidupan sehari-hari, hal ini penerapan di bidang ekonomi. Matematika memiliki karakteristik yang berbeda dengan mata pelajaran yang lain, sebab pada dasarnya obyek matematika adalah abstrak, sehingga beberapa mahasiswa terkadang mengalami permasalahan atau kesulitan dalam mengaitkan konseptual yang sudah ada dalam matematika ke bidang ekonomi. Terlebih lagi setiap mahasiswa memiliki karakteristik yang berbeda-beda sehingga permasalahan atau kesulitan yang ditemui setiap mahasiswapun juga berbeda satu sama lainnya. (Tanjung, 2012) mengatakan bahwa kesulitan 
belajar tidak hanya dialami oleh peserta didik yang berkemampuan di bawah rata-rata, tetapi bisa juga dialami oleh peserta didik dengan tingkat kemampuan yang lain. Hal inilah yang ditemui peneliti dalam setiap proses pembelajaran, khususnya dalam mata kuliah matematika ekonomi.

Pengetahuan matematika yang ada pada setiap mahasiswa merupakan bagian dari kemampuan berpikir matematis, hal ini bertujuan untuk memecahkan masalah yang ada dalam pembelajaran. Tujuan pembelajaran dari mata kuliah matematika ekonomi salah satunya adalah memberikan suatu pemahaman kepada mahasiswa tentang matematika sebagai alat bantu dalam menganalisis model-model ekonomi, misalkan materi fungsi linier yang berkaitan dengan fungsi permintaan dan penawaran dari suatu barang atau jasa dan masih banyak lainnya. Jadi tidak heran apabila ada beberapa mahasiswa yang merasa kesulitan, dikarenakan adanya tuntutan untuk dapat memahami konsep matematika dengan baik lalu mengaplikasikannya dalam bidang ekonomi.

Berdasarkan hasil nilai akhir mahasiswa mata kuliah matematika ekonomi pada tahun akademik 2019/2020, diperoleh masih ada beberapa mahasiswa yang mengikuti ujian perbaikan. Hal ini menandakan bahwa masih ada mahasiswa yang belum tuntas dengan nilai akhirnya dan berdampak mata kuliah tersebut masih dianggap sebagai mata kuliah yang sulit. Timbulnya kesulitan ini berawal dari adanya permasalahan pada diri mahasiswa yang tidak tersampaikan dengan baik pada saat proses pembelajaran, karena kesulitan yang dialami mahasiswa banyak faktor yang mempengaruhi, bisa datang dari dalam diri maupun dari luar diri mereka. Misalnya bisa dari strategi pembelajaran ataupun pada saat proses pembelajaran yang menuntut mahasiswa aktif. Hal ini sependapat dengan (Nofiansyah, 2015) yang menyatakan kesulitan yang dialami peserta didik dalam memecahkan masalah tidak berarti peserta didik tersebut belum bisa menjawab atau menyelesaikannya, tetapi bisa saja dikarenakan peserta didik belum bisa mengetahui permasalahan yang ia terima pada proses pembelajaran matematika. Permasalahan yang timbul apabila tidak mendapat respon dengan tepat, maka akan berdampak pada hasil yang dicapai oleh mahasiswa dan itu sudah terbukti dari hasil nilai akhir yang diperoleh. Alhasil akan muncul anggapan bahwa mata kuliah 
matematika ekonomi adalah mata kuliah yang sulit untuk mendapatkan nilai akhir maksimal. Sehingga perlu adanya proses pembelajaran yang menuntut mahasiswa aktif ketika pembelajaran berlangsung, sebab aktifnya mahasiswa dapat meningkatkan pemahaman konsep terhadap suatu materi sehingga nilai akhir dari mata kuliah matematika ekonomi pun akan meningkat. Keaktifan ini bisa ditandai dari tingkat kepercayaan diri (self efficacy) mahasiswa. Timbulnya self efficacy mahasiswa ada kaitannya mengenai strategi pembelajaran yang diterapkan dalam proses pembelajaran.

Berdasarkan hasil pengamatan dan evaluasi dari nilai akhir mahasiswa di tahun akademik sebelumnya, peneliti mendapatkan kurang maksimalnya proses pembelajaran konvensional yang telah dilakukan. Sebab menurut (Hamalik, 2008), salah satu kriteria suatu proses pembelajaran dikatakan berhasil yaitu apabila peserta didik mencapai tujuan yang telah ditentukan. Sehingga peneliti mencoba untuk mengoptimalkan self efficacy dari pembelajaran konvensional tersebut dibantu dengan penerapan scaffolding pada proses pembelajaran. Scaffolding merupakan pemberian bantuan/bimbingan oleh dosen kepada mahasiswa dalam proses pembelajaran disaat mahasiswa mengalami permasalahan dan secara bertahap mulai menghentikan bantuan tersebut dirasa apabila mahasiswa sudah mampu untuk menyelesaikan permasalahan yang dihadapinya. Pemberian bantuan yang tepat dan jelas bagi peserta didik adalah di saat anak (mahasiswa) merasa kesulitan dalam menyelesaikan permasalahannya, sehingga peserta didik dapat mencapai tingkat pengembangan potensi dalam memahami dan membangun pengetahuan matematika (Machmud, 2011).

Scaffolding merupakan salah satu ide atau gagasan penting dari Vygotsky, pemberian bantuan/dukungan ini sejalan dengan pengertian Zone of Proximal Development (ZPD) dari Vygotsky dimana pemberian bantuan oleh pendidik kepada peserta didik pada proses pembelajaran dengan porsi yang tepat. Penerapan scaffolding tidak hanya mengaitkan motivasi mahasiswa dengan tugas, namun juga dapat mengembangkan self efficacy, yang mana merupakan aspek psikologi mahasiswa dalam menyelesaikan masalah yang disajikan. Self efficacy yang dimaksud 
adalah keyakinan mahasiswa mengenai kemampuan dirinya dalam melakukan suatu pekerjaan atau tugas tertentu. Self efficacy ini nantinya akan memberikan kontribusi guna memunculkan kepercayaan diri pada mahasiswa dalam menyelesaikan masalah. Diharapkan dengan meningkatnya self efficacy maka nilai akhir mahasiswa akan meningkat. Hal ini sependapat dengan (Liu, 2009) yang menyatakan bahwa prestasi matematika dan kepercayaan diri memiliki hubungan yang positif. Menilik dari pendapat tersebut maka dengan adanya beberapa mahasiswa yang mengikuti ujian perbaikan menandakan ada permasalahan yang muncul berkaitan dengan self efficacy mahasiswa selama proses pembelajaran mata kuliah matematika ekonomi.

Pada mata kuliah matematika ekonomi yang relatif dianggap sulit oleh mahasiswa adalah pada saat memecahkan masalah, mahasiswa yang mempunyai self efficacy tinggi menganggap kegagalan sebagai kurangnya usaha, sedangkan mahasiswa yang memiliki self efficacy rendah menganggap kegagalan berasal dari kurangnya kemampuan. Tinggi rendahnya self efficacy ini tidak muncul dengan sendirinya, namun bisa dari beberapa faktor. Menurut (Hidayat, 2015) mengatakan bahwa self efficacy bisa diperoleh dari pengalaman diri sendiri, pengalaman orang lain, berbagi ilmu pengetahuan dan interaksi dengan orang lain. Maka dalam permasalahan ini, diharapkan dengan adanya penerapan scaffolding pada proses pembelajaran, mahasiswa akan mengalami peningkatan self efficacy, selanjutnya berpengaruh terhadap peningkatan nilai akhir. Sependapat dengan (Akhtar, 2014) yang menyatakan bahwa scaffolding sangat membantu dalam meningkatkan tingkat rasa percaya diri bagi peserta didik yang berprestasi rendah dalam pembelajaran matematika.

Berdasarkan uraian permasalahan yang timbul di atas, maka peneliti kemudian tertarik untuk melakukan penelitian mengenai efektivitas penerapan scaffolding terhadap self efficacy mahasiswa pada pembelajaran mata kuliah matematika ekonomi.

\section{METODE PENELITIAN}

Jenis penelitian ini termasuk pendekatan penelitian eksperimen, dimana menurut (Sanjaya, 2015) penelitian eksperimen bertujuan untuk 
mengetahui pengaruh suatu tindakan atau perlakuan yang sengaja dilakukan terhadap situasi tertentu. Penelitian ini menggunakan desain one groups pretest-postest design. Dimana hasil dapat dilihat dari sebelum diberikan perlakuan dan setelah diberikan perlakuan berupa penerapan scaffolding dalam proses pembelajaran. Tujuan penelitian ini adalah untuk mengetahui efektivitas penerapan scaffolding terhadap self efficacy mahasiswa pada mata kuliah matematika ekonomi. Pada Gambar 1 di bawah ini menunjukkan desain penelitian one group pretest-postest design (Sugiyono, 2014).

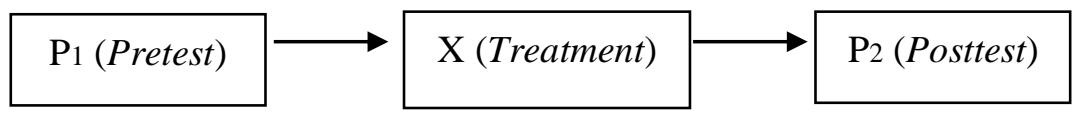

\section{Gambar 1. Desain Penelitian}

Populasi dalam penelitian ini adalah seluruh mahasiswa semester IV Pendidikan Ekonomi Tahun Akademik 2020/2021, sedangkan teknik sampel dalam penelitian ini adalah dengan sampling jenuh, dimana teknik penentuan sampel apabila semua anggota populasi digunakan sebagai sampel, yaitu populasi relatif kecil (Sugiyono, 2014). Sampel berupa mahasiswa semester IV yang berjumlah 30. Selanjutnya untuk teknik pengumpulan data menggunakan angket berupa checklist dengan skala Likert. Dimana angket tersebut digunakan untuk mengetahui self efficacy mahasiswa dalam pembelajaran. Berikut ini Tabel 1 mengenai indikator skala self efficacy.

Tabel 1. Aspek Penilaian Self efficacy

\begin{tabular}{|c|c|c|c|c|}
\hline $\mathrm{No}$ & Aspek & Deskripsi & \multicolumn{2}{|c|}{ Indikator } \\
\hline 1 & $\begin{array}{c}\text { Authentic } \\
\text { mastery } \\
\text { experiences } \\
\text { (Pencapaian } \\
\text { Kinerja) }\end{array}$ & $\begin{array}{lr}\text { Indikator } & \text { kemampuan } \\
\text { yang } & \text { didasarkan } \\
\text { kinerja pengalaman } & \text { sebelumnya }\end{array}$ & $\begin{array}{ll}\text { 1. } & \begin{array}{l}\text { Pandangan } \\
\text { terhadap }\end{array} \\
\text { matematika } \\
\text { dimilikinya. }\end{array}$ & $\begin{array}{r}\text { mahasiswa } \\
\text { kemampuan } \\
\text { yang } \\
\text { mahasiswa } \\
\text { keterampilan }\end{array}$ \\
\hline 2 & $\begin{array}{c}\text { Vicarious } \\
\text { experiences }\end{array}$ & $\begin{array}{l}\text { Bukti yang didasarkan } \\
\text { pada kompetensi dan }\end{array}$ & $\begin{array}{l}\text { Kemampuan } \\
\text { membanding }\end{array}$ & mahasiswa \\
\hline
\end{tabular}




\begin{tabular}{|c|c|c|c|}
\hline & $\begin{array}{l}\text { (Pengalaman } \\
\text { Orang Lain) }\end{array}$ & perbandingan & 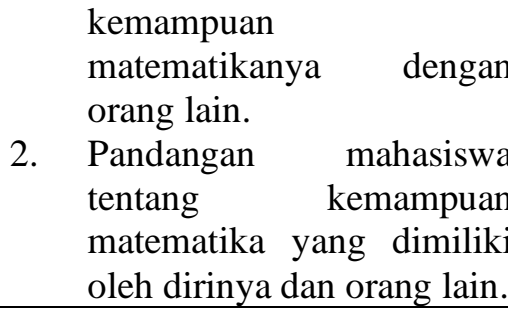 \\
\hline 3 & $\begin{array}{l}\text { Verbal } \\
\text { persuasions } \\
\text { (Persuasi } \\
\text { Verbal) }\end{array}$ & $\begin{array}{l}\text { Mengacu pada umpan } \\
\text { balik langsung atau } \\
\text { kata-kata guru atau } \\
\text { orang yang lebih } \\
\text { dewasa }\end{array}$ & $\begin{array}{l}\text { Kemampuan } \\
\text { memahami makna kalimat } \\
\text { matematis dalam soal-soal } \\
\text { berpikir kreatif matematis. }\end{array}$ \\
\hline 4 & $\begin{array}{l}\text { Physiological } \\
\text { indexes } \\
\text { (Indeks } \\
\text { Psikologis) }\end{array}$ & $\begin{array}{lr}\text { Penilaian } & \text { terhadap } \\
\text { kemampuan, } & \\
\text { kelebihan, } & \text { dan } \\
\text { kelemahan tentang } \\
\text { suatu tugas atau } \\
\text { pekerjaan }\end{array}$ & 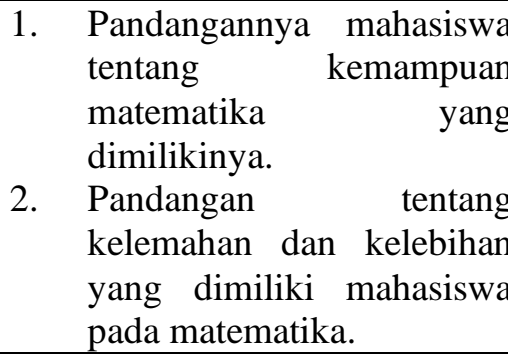 \\
\hline
\end{tabular}

Sumber: (Noer, 2012)

Sebelum digunakan dalam penelitian, skala self efficacy diujicobakan untuk mengetahui validitas dan reliabilitasnya. Selanjutnya untuk teknik analisis data dalam penelitian ini menggunakan pendekatan analisis kuantitatif, hal ini didasarkan pada data yang diperoleh berupa data kuantitatif, yaitu hasil dari angket self efficacy yang diberikan ke mahasiswa. Pengambilan data ini dengan pemberian angket sebelum penerapan scaffolding atau proses pembelajaran secara konvensional dan setelah penerapan scaffolding pada proses pembelajaran mata kuliah matematika ekonomi. Sebelum dianalisis dengan uji statistik perlu dilakukannya uji prasyarat, yaitu uji normalitas. Adapun Rumus yang dapat dipakai untuk uji normalitas adalah dengan metode KolmogorovSmirnov. Kemudian dilanjutkan untuk uji $t$ dan uji effect size untuk mengetahui kategori efektivitas self efficacy mahasiswa. 
Rumus yang dapat digunakan dalam uji- $t$ ini ialah:

$$
t_{\text {hit }} \frac{\bar{D}}{\frac{S D}{\sqrt{n}}}
$$

Diperhatikan bahwasannya:

$$
\begin{gathered}
S D=\sqrt{\operatorname{var}} \\
\operatorname{var}\left(s^{2}\right)=\frac{1}{n-1} \sum_{i=1}^{n}\left(x_{i}-\bar{x}\right)^{2}
\end{gathered}
$$

Keterangan:

$t \quad=$ nilai $t$ hitung

$\bar{D} \quad=$ rata-rata selisih pengukuran pertama dan kedua

$S D=$ standar deviasi selisih pengukuran pertama dan kedua

$n \quad$ = jumlah sampel

Selanjutnya untuk Rumus uji effect size (d) (Dunst, 2004) adalah:

$$
d=\frac{\left(M_{I}-M_{B}\right)}{S D_{P}}
$$

Diperhatikan bahwasannya:

$$
S D_{P}=\sqrt{\frac{\left(S D_{B}^{2}+S D_{I}^{2}\right)}{2}}
$$

Keterangan:

$\mathrm{d} \quad=$ effect size

$M_{I} \quad=$ rata-rata post-test

$M_{B} \quad=$ rata-rata pre-test

$S D_{P}=$ standar deviasi pooled

Selanjutnya untuk mengetahui kategori nilai effect size dapat dilihat pada Tabel 2 di bawah ini. 
Tabel 2. Pedoman Interpretasi Nilai Effect Size

\begin{tabular}{cc}
\hline Interval Koefisien & Tingkat Hubungan \\
\hline $0,00-0,199$ & Sangat rendah \\
\hline $0,20-0,399$ & Rendah \\
\hline $0,40-0,599$ & Sedang \\
\hline $0,60-0,799$ & Kuat \\
\hline $0,80-1,000$ & Sangat Kuat \\
\hline
\end{tabular}

Dalam analisis data ini, peneliti menggunakan bantuan aplikasi SPSS versi 24.

\section{HASIL PENELITIAN DAN PEMBAHASAN}

Berdasarkan data yang diperoleh dan analisis yang dilakukan peneliti, maka uji instrumen untuk angket self efficacy diperoleh dari 34 butir pertanyaan/pernyataan didapat 30 butir pertanyaan/pernyataan yang valid dengan indeks konsistensi lebih dari 0,30 dan memiliki indeks reliabilitas sebesar 0,72. Hasil di atas, maka angket tersebut memenuhi kriteria angket yang layak digunakan untuk mengambil data. Selanjutnya untuk uji normalitas diperoleh nilai sig sebesar 0,200, yang mana nilai tersebut lebih dari 0,05 maka dapat disimpulkan data berdistribusi normal.

Setelah didapat data berdistribusi normal, maka dilakukan uji hipotesis (uji-t). Hasil yang didapat dari olah data dengan bantuan aplikasi SPSS Versi 24 terlihat pada Tabel 3, 4, dan 5 di bawah ini.

\section{Tabel 3. Paired Samples Statistics}

Paired Samples Statistics

\begin{tabular}{|c|c|c|c|c|c|}
\hline & & Mean & $N$ & Std. Deviation & Std. Error Mean \\
\hline \multirow{2}{*}{ Pair 1} & Pre-test & 74.87 & 30 & 7.389 & 1.349 \\
\hline & Post-test & 79.00 & 30 & 6.948 & 1.269 \\
\hline
\end{tabular}

Berdasarkan hasil statistik deskriptif pada Tabel 3 dapat dijelaskan bahwa nilai rata-rata pre-test sebesar 74,87 < nilai rata-rata post-test sebesar 79,00, ini menandakan adanya perbedaan nilai rata-rata dari hasil angket self efficacy mahasiswa antara sebelum penerapan scaffolding (pembelajaran konvensional) dengan sesudah penerapan scaffolding pada mata kuliah matematika ekonomi. Ini membuktikan bahwa self efficacy 
mahasiswa mengalami peningkatan setelah penerapan scaffolding dalam proses pembelajaran, sebab timbulnya self efficacy ketika mahasiswa mulai memahami dengan baik konsep materi tersebut. Peningkatan ini terjadi salah satunya dikarenakan adanya interaksi sosial antar mahasiswa saat bekerja sama, kepercayaan diri mahasiswa terlihat dalam menyelesaikan masalah yang ditemui. Ketika mahasiswa lain berhasil menyelesaikan suatu permasalahan dengan baik, maka mahasiswa tersebut akan memiliki penilaian yang baik pula tentang keberhasilannya sendiri dalam menyelesaikan permasalahan yang sama, disini mahasiswa mulai membandingkan kemampuan matematikanya dengan orang lain. Sehingga proses kepercayaan dirinya dapat berkembang atau mengalami peningkatan. Hal ini senada dengan yang diungkapkan oleh (Zeldin, 2000) menyatakan bahwa dengan mengamati keberhasilan orang lain, siswa dapat melakukan penilaian terhadap kemampuan dirinya sendiri.

\section{Tabel 4. Paired Samples Correlations}

Paired Samples Correlations

\begin{tabular}{rrrrrr} 
& & $N$ & Correlation & \multicolumn{1}{l}{ Sig. } \\
\hline Pair 1 & Pre-test \& Post-test & 30 & .502 & .005 \\
\hline
\end{tabular}

Berdasarkan Tabel 4, terlihat bahwa nilai sig. 0,005 $<0,05$, ini menandakan adanya korelasi antara variabel pre-test dengan variabel post-test. Kemudian untuk nilai koefisien korelasinya sebesar 0,502, ini menandakan tingkat hubungan sedang antara variabel pre-test dengan variabel post-test.

\section{Tabel 5. Paired Samples Test}

Paired Samples Test

Paired Differences

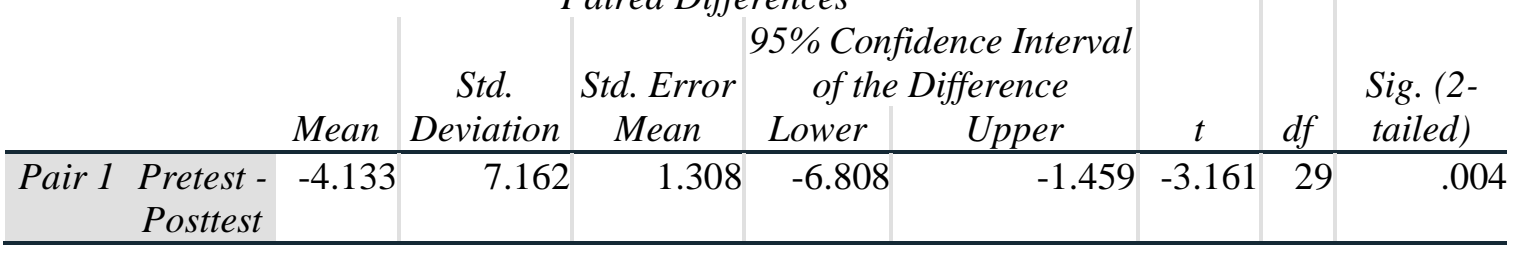


Berdasarkan Tabel 5, terlihat bahwa nilai $t_{\text {hitung }}$ sebesar 3,161 > $t_{\text {tabel }}$ sebesar 2,045, ini menandakan adanya perbedaan rata-rata hasil angket self efficacy, sehingga dapat dikatakan penerapan scaffolding efektif terhadap self efficacy mahasiswa pada mata kuliah matematika ekonomi. Penerapan scaffolding yang tepat dan jelas oleh peneliti ketika mahasiswa merasa kesulitan dalam menyelesaikan masalah yang dihadapi akan meningkatkan self efficacy mahasiswa, ini menyangkut mengenai kemampuan mahasiswa dalam memaknai konsep dan menyelesaikan permasalahan, sehingga selanjutnya akan berdampak pada nilai akhir mata kuliah matematika ekonomi. Hal ini didukung oleh (Manafe et al, 2016) yang menyatakan peserta didik yang memiliki self efficacy tinggi dapat meningkatkan performa akademik dengan demikian self efficacy sangat berpengaruh terhadap hasil belajar peserta didik.

Selanjutnya menentukan efektivitas dari penerapan scaffolding pada proses pembelajaran, diperoleh dari uji effect size.

$$
\begin{aligned}
& d=\frac{\left(M_{I}-M_{B}\right)}{\sqrt{\frac{\left(S D_{B}^{2}+S D_{I}^{2}\right)}{2}}} \\
& =\frac{(79,00-74,89)}{\sqrt{\frac{\left(7,389^{2}+6,948^{2}\right)}{2}}} \\
& =\frac{4,133}{7,162} \\
& =0,577
\end{aligned}
$$

Dari perhitungan di atas, terlihat bahwasannya nilai $d=0,577$, ini menandakan tingkat hubungan sedang.

Penerapan scaffolding pada proses pembelajaran yang berupa mengarahkan pekerjaan mahasiswa, menyajikan rincian dengan jelas dan mengurangi kebingungan mahasiswa pada pembelajaran, memunculkan pertanyaan mengarahkan, mengevaluasi hasil pekerjaan untuk mengklarifikasi kebenarannya merupakan hal yang sering dilakukan oleh peneliti. Dimana hal tersebut menjadikan proses pembelajaran lebih 
terarah dan dapat meningkatkan self efficacy mahasiswa. Self efficacy timbul pada saat mahasiswa mulai memahami materi dengan baik dan pembelajaran aktif muncul dengan sendirinya. Self efficacy yang positif akan mempengaruhi mahasiswa dalam pengambilan keputusan dan mempengaruhi tindakan yang akan dilakukannya (Noer, 2012).

\section{SIMPULAN}

Berdasarkan hasil penelitian dan pembahasan diperoleh simpulan bahwa penerapan scaffolding memberikan dampak pada self efficacy mahasiswa dalam proses pembelajaran. Salah satunya mengenai kemampuan mahasiswa dalam membandingkan kemampuan matematikanya dengan temannya saat kerja sama serta kemampuan dalam memaknai konsep dalam menyelesaikan permasalahan. Self efficacy mahasiswa timbul dari motivasi yang diberikan oleh peneliti, pemilihan suatu cara yang tepat dalam menyelesaikan permasalahan (tidak merusak kepercayaan), dan pengetahuan mahasiswa dalam proses pembelajaran. Self efficacy yang cenderung rendah akan membentuk pola kegagalan sebelum mencoba, namun apabila self efficacy yang tinggi akan cenderung untuk membentuk pola keberhasilan dalam menyelesaikan permasalahan walaupun belum mencobanya. Selanjutnya dalam penetian ini, penerapan scaffolding efektif terhadap self efficacy mahasiswa pada mata kuliah matematika ekonomi, hal ini dapat terlihat dari hasil pre-test dan post-test pada penyebaran angket. Terlihat ada perbedaan antara sebelum dan sesudah penerapan scaffolding terhadap self efficacy mahasiswa. Selanjutnya untuk hasil uji effect size termasuk kategori sedang.

\section{DAFTAR PUSTAKA}

Akhtar, M. (2014). Patterns of Scaffolding in One-to-One Mathematics Teaching: An Analysis. Educational Research International, 3(1), 71-79.

Dunst, C. H. (2004). Guidelines for Calculating Effect Sizes. Centerscope, 3(1), 1-10.

Hamalik, O. (2008). Kurikulum dan Pembelajaran. Jakarta: Bumi Aksara. 
Hidayat, D. (2015). Teorema dan Aplikasi Psikologi Kepribadian dalam Konsling. Jakarta: Ghalia Indonesia.

Liu, X. (2009). The Effect of Mathematics Self-efficacy on Mathematics Achievement of High School Students. NERA Conference Proceedings. University of Connecticut.

Machmud, T. (2011). Scaffolding Strategy in Mathematics Learning. Proceeding International Seminar and the Fourth National Conference on Mathematics Education. ISBN: 9778-979-16353-7-0, pp. 429-440. Yogyakarta: Yogyakarta State University.

Manafe, Y., Setyosari, P., Kuswandi, D., \& Ulfa, S. (2016). Pengaruh Strategi Kerjasama Kelompok dan Efikasi Diri terhadap Hasil Belajar Keterampilan Teknikal. Jurnal Pendidikan Humaniora, 4(3), 152162.

Noer, S. H. (2012). Self Efficacy Mahasiswa Terhadap Matematika. Seminar Nasional Pendidikan Matematika FMIPA. ISBN: 978-97916353-8-7. Yogyakarta: Universitas Negeri Yogyakarta.

Nofiansyah, W. S. (2015). Analisis Proses Scaffolding pada Pembelajaran Matematika di Kelas VIII SMP Negeri 4 Karanganyar Tahun Pelajaran2013/2014. Jurnal Elektronik Pembelajaran Matematika, 9(3), 947-958.

Sanjaya, W. (2015). Penelitian Pendidikan Jenis, Metode dan Prosedur. Jakarta: Prenadamedia Grup.

Sugiyono. (2014). Metode Penelitian Kuantitatif, Kualitatif, dan $R \& D$. Bandung: Alfabeta.

Tanjung, R. D. (2012). Diagnosis Kesulitan Belajar Matematika SMP pada Materi Persamaan Garis Lurus. Unnes Journal of Mathematics Education, 1(1), 52-57.

Zeldin, A. (2000). Sources and Effects of the Self-Efficacy Beliefs of Men with Careers in Mathematics, Science, and Technology. Emory University. Disertasi: tidak dipublikasikan. [Online]. Tersedia: http://www.des.emory.edu/mfp/ZeldinDissertation2000.PDF 
176 | Nofiansyah: Efektivitas Penerapan Scaffolding terhadap ... 